\title{
PENGONTROLAN BAHAN BAKU PRODUKSI SEMEN JENIS PCC DI PT. SEMEN PADANG DENGAN MENGGUNAKAN DIAGRAM KONTROL MEWMA
}

\author{
SURYA PUSPITA SARI, DODI DEVIANTO, FERRA YANUAR \\ Program Studi Matematika, \\ Fakultas Matematika dan Ilmu Pengetahuan Alam, Universitas Andalas, \\ Kampus UNAND Limau Manis Padang, Indonesia, \\ email : surya.p.sari@gmail.com
}

\begin{abstract}
Abstrak. Terdapat berbagai bidang industri di dunia ini, dimana setiap perusahaan selalu berusaha memberikan kualitas terbaik mereka. Semen adalah salah satu produk industri yang dibutuhkan oleh banyak orang. Perusahaan yang bergerak di bidang industri semen seperti PT. Semen Padang membutuhkan suatu informasi tentang kualitas produksinya. Bahan baku adalah salah satu faktor yang mempengaruhi kualitas produk yang dihasilkan. Terdapat beberapa komponen senyawa yang mempengaruhi kualitas bahan baku semen, yaitu $\mathrm{SiO}_{2}, \mathrm{Al}_{2} \mathrm{O}_{3}, \mathrm{CaO}$ dan $\mathrm{SO}_{3}$. Di dalam penelitian ini dibahas tentang kualitas bahan baku produksi semen jenis PCC, yang diukur dari persentase komponen senyawa yang mempengaruhi bahan baku semen tersebut. Metode statistika yang digunakan adalah diagram kontrol Multivariate Exponentially Weighted Moving Average (MEWMA) untuk mengontrol variabel karakteristik kualitas. Dengan memilih $A R L_{0}$ sebesar 5500 dan menggunakan beberapa nilai pembobot, diperoleh bahwa nilai pembobot sebesar 0,73 akan menghasilkan diagram kontrol MEWMA optimal dengan satu pengamatan bersifat out of control. Melalui konfirmasi yang dilakukan kepada pihak PT. Semen Padang, pengamatan out of control pada hari tertentu akan segera dideteksi dan dilakukan perbaikan kualitas pada pengamatan berikutnya. Bahan baku yang kurang baik akan dicampurkan dengan bahan baku berkualitas baik di dalam silo sehingga tetap menghasilkan bahan baku semen yang kualitasnya terjaga. Indeks Cp dari masing-masing variabel menunjukkan bahwa bahan baku produksi semen sudah baik, namun indeks Cpk menunjukkan ketidak akuratan pengukuran pada salah satu komponen bahan baku semen yaitu $\mathrm{CaO}$.
\end{abstract}

Kata Kunci: Diagram kontrol Multivariate Exponentially Weighted Moving Average, $A R L_{0}$, batas kontrol atas, analisis kemampuan proses

\section{Pendahuluan}

Sumatera Barat sebagai salah satu provinsi di Indonesia yang saat ini terus melakukan percepatan pembangunan untuk peningkatan kesejahteraan dan daya saing. Provinsi yang terletak di pantai barat Pulau Sumatera ini terus melakukan aktivitas pembangunan dari berbagai sektor. Hal ini bertujuan untuk mendukung upaya peningkatan kesejahteraan dan peningkatan kualitas serta sarana prasarana sehingga dapat memberikan dampak positif dalam sektor pembangunan. Target pemerintah Provinsi Sumatera Barat untuk tahun 2016 yaitu seluruh jalan di Sumatera Barat kondisinya mantap dan terwujud sesuai rencana. Secara nasional, kondisi infrastruktur jalan provinsi mencapai 65 persen dan infrastruktur jalan na- 
sional mencapai 90 persen.

Semen adalah salah satu bahan baku utama yang sangat penting untuk menyertai pembangunan infrastruktur tersebut. Selain target penyelesaian pembangunan, tentu infrastrukur yang dibangun harus tahan lama. Oleh karena itu dibutuhkan bahan baku yang kualitasnya baik. Baiknya kualitas semen tentu sangat dipengaruhi oleh bahan baku produksinya. PT. Semen Padang sebagai satu-satunya perusahaan semen yang ada di Sumatera Barat mengakibatkan PT. Semen Padang menjadi produsen utama yang memenuhi permintaan pasar khususnya di Sumatera Barat. Oleh karena itu, perlu dilakukan pengontrolan bahan baku produksi semen di PT. Semen Padang untuk menjaga hasil produksi agar tetap menjadi nomor satu. Seperti halnya perusahaan-perusahaan dalam industri lainnya, untuk menghasilkan produk yang memenuhi keinginan konsumen, PT. Semen Padang harus secara terus menerus mengendalikan kualitasnya. Terdapat beberapa variabel yang harus dikendalikan oleh PT. Semen Padang dalam bahan baku produksinya sebagaimana yang telah ditetapkan oleh SNI (Standar Nasional Indonesia). Untuk tipe Portland Composite Cement (PCC), variabel yang dikendalikan dari bahan dasar pembentuk semen tersebut adalah batu kapur $\mathrm{CaO}$, lempung yang mengandung $\mathrm{SiO}_{2}$ dan $\mathrm{Al}_{2} \mathrm{O}_{3}$ serta bahan lain, yaitu $\mathrm{SO}_{3}$.

Beragam cara dapat dilakukan oleh suatu industri untuk mengendalikan barang atau jasa yang dihasilkan. Salah satu cara pengendalian kualitas secara statistika yaitu dengan menggunakan pengendalian kualitas proses secara statistik atau Statistical Process Control (SPC). Diagram kontrol merupakan salah satu alat dalam mengontrol proses secara statistik yang berfungsi untuk mengendalikan suatu variabel dari kualitas. Bila terdapat lebih dari satu variabel, maka diagram kontrol yang digunakan adalah diagram kontrol multivariat. Diagram kontrol Multivariate Exponentially Weighted Moving Average (MEWMA) adalah salah satu diantaranya. Diagram kontrol MEWMA merupakan diagram kontrol multivariat yang lebih efektif dalam mendeteksi pergeseran vektor mean yang kecil. Penelitian Reynolds dan Cho (2006), mengembangkan diagram kontrol MEWMA untuk target mean proses dan memonitor variabilitas proses.

Semen memiliki lebih dari satu komponen yang terkandung di dalam bahan bakunya. Komponen semen pada saat ini menjadi variabel kualitas yang akan diteliti dalam proses pengendalian kualitas. PT. Semen Padang sebagai perusahaan besar yang ada di Sumatera Barat tentu harus memiliki ketelitian yang tinggi dalam proses produksinya. Oleh karena itu diagram kontrol MEWMA menjadi diagram yang cocok dalam penelitian ini karena diagram kontrol MEWMA dapat menjadi alat pengendalian kualitas dengan lebih dari satu variabel dan tingkat ketelitian yang tinggi. Nilai pembobot yang semakin kecil akan memperoleh diagram kontrol MEWMA yang lebih teliti. Dalam hal ini juga perlu dilakukan analisis kemampuan proses untuk mengetahui bagaimana proses yang terjadi dan keakuratan dari pengukuran yang telah dilakukan ketika proses produksi berlangsung. Untuk itu dalam penelitian ini akan dikaji tentang pengontrolan bahan baku produksi semen jenis PCC di PT. Semen Padang dengan menggunakan diagram kontrol MEWMA. 


\section{Diagram Kontrol MEWMA}

Suatu perpanjangan multivariat langsung dari diagram kontrol EWMA univariat pertama kali diperkenalkan oleh Lowry, Woodal, Champ, dan Rigdon pada tahun 1992. Mereka mengembangkan diagram kontrol multivariat EWMA (MEWMA). Metode ini merupakan perluasan dari EWMA univariat. Diagram kontrol MEWMA pada penelitian ini digunakan untuk pengamatan individual. Vektor MEWMA akan dijelaskan pada persamaan berikut [4]:

$$
Z_{i}=\lambda X_{i}+(1-\lambda) Z_{i-1}
$$

Diagram kontrol MEWMA dapat menggunakan nilai pembobot yang sama atau tidak. Namun dalam penelitian ini digunakan nilai pembobot yang sama karena tidak ada asumsi dari perusahaan yang menyatakan adanya kepentingan dari setiap variabel karakerisik kualitas.

Akan ditentukan matriks varians kovarian dengan rumus sebagai berikut:

$$
\Sigma_{Z_{i}}=\frac{\lambda}{2-\lambda}\left[1-(1-\lambda)^{2 i}\right] \Sigma_{X}, \quad i=1,2, \ldots, n .
$$

Untuk perhitungan nilai MEWMA pada titik pengamatan akan dijelaskan pada persamaan berikut:

$$
T_{i}=Z_{i}^{T} \Sigma_{Z_{i}}^{-1} Z_{i}, \quad i=1,2, \ldots, n .
$$

Batas kontrol atas (BKA) dari diagram kontrol MEWMA adalah sebagai berikut:

$$
B K A=H .
$$

\subsection{Menentukan $A R L_{0}$ pada Diagram Kontrol MEWMA}

$A R L_{0}$ adalah salah satu nilai yang digunakan dalam membentuk diagram kontrol MEWMA. $A R L_{0}$ adalah nilai ARL pada saat data terkontrol. Semakin besar nilai $A R L_{0}$ maka semakin efektif diagram kontrol tersebut. Akan ditentukan diagram kontrol MEWMA dengan memilih besar nilai pembobot $\lambda=1$. Bandingkan diagram kontrol MEWMA yang dihasilkan dengan diagram kontrol $T^{2}$ Hotelling yang telah diperoleh sebelumnya. Pilih $A R L_{0}$ yang membuat diagram kontrol MEWMA dengan $\lambda=1$ ekivalen terhadap diagram kontrol $T^{2}$ Hotelling.

Nilai $H$ adalah sebuah nilai yang dipengaruhi oleh banyak variabel $(p)$, besar pembobot $(\lambda)$ dan $A R L$ dalam data terkendali $\left(A R L_{0}\right)$. Data dalam keadaan terkendali pada diagram kontrol dikonstruksi dengan data standardized [3].

Batas kontrol bawah (BKB) dari diagram kontrol MEWMA adalah sebagai berikut:

$$
B K B=0 .
$$

Dari Gambar 2 diketahui bahwa diagram kontrol MEWMA dengan $A R L_{0}=$ 5500 ekivalen dengan diagram kontrol $T^{2}$ Hotelling pada Gambar 1 yaitu memiliki nilai statistik yang sama pada setiap pengamatan dan nilai batas kontrol atas yang sama. Oleh karena itu dalam penelitian ini dipilih $A R L_{0}=5500$. 


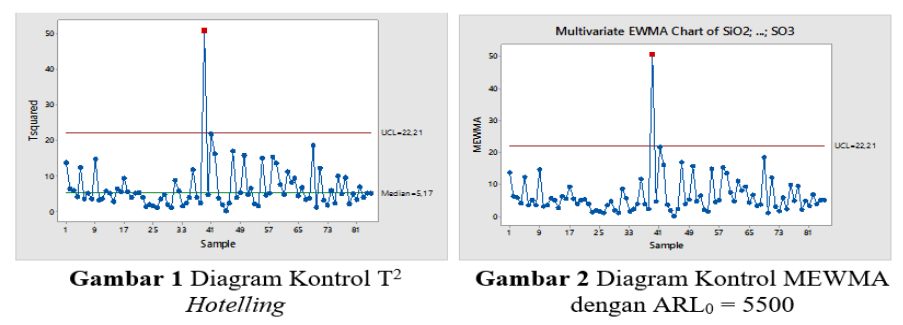

\subsection{Penerapan Diagram Kontrol MEWMA}

Tujuan utama penerapan diagram kontrol MEWMA adalah melakukan pengontrolan terhadap mean proses dengan pengambilan sampel individual. Diagram kontrol MEWMA dapat langsung digunakan tanpa adanya pengontrolan tahap pertama yang mempunyai tujuan mengestimasi variabel yang digunakan untuk mengontrol pada tahap kedua. Pada penelitian ini tidak dibedakan pengontrolan tahap pertama dan tahap kedua, tetapi langsung dilakukan pengontrolan mean proses berdasarkan data bulan Januari sampai Maret 2015.

Penerapan diagram kontrol MEWMA pada penelitian ini menggunakan nilai pembobot $\lambda=0,25, \lambda=0,5, \lambda=0,75$ dan $\lambda=1$. Sebelum membentuk diagram kontrol MEWMA, langkah yang harus dilakukan terlebih dahulu adalah membakukan data yang akan diolah. Berikut adalah matriks varians kovarian dari data yang sudah dibakukan.

$$
\Sigma_{x}=\left(\begin{array}{cccc}
0.645108 & 0,361579 & -0,21008 & 18792 \\
0,361579 & 0,473218 & -0,16014 & -0,16636 \\
-0,21008 & -0,16014 & 0,756993 & 0,082795 \\
-0,18792 & -0,16636 & 0,082795 & 0,457025
\end{array}\right)
$$

Berdasarkan pembahasan di atas, diketahui bahwa pembobot sebesar 0,75 dan 1 menghasilkan diagram kontrol yang optimal dengan 1 pengamatan out of control. Oleh karena itu, dengan cara yang sama seperti pembahasan di atas, akan dicari pembobot sebesar $\lambda<0,75$ untuk memperoleh nilai pembobot yang lebih kecil. Pengamatan dihentikan karena pada pembobot sebesar 0,72 jumlah pengamatan out of control bertambah. Oleh karena itu, dari pembahasan di atas diketahui bahwa pembobot sebesar $0,73,0,74,0,75$ dan 1 telah menghasilkan diagram kontrol optimal dengan 1 pengamatan out of control.

\subsection{Analisis Diagram Kontrol MEWMA}

Hasil dari diagram kontrol MEWMA untuk empat variabel yaitu $\mathrm{SiO}_{2}, \mathrm{Al}_{2} \mathrm{O}_{3}, \mathrm{CaO}$ dan $\mathrm{SO}_{3}$ pada bahan baku semen jenis PCC PT. Semen Padang menunjukkan bahwa diagram kontrol MEWMA optimal menghasilkan satu pengamatan out of control dengan pembobot sebesar $\lambda=0,73, \lambda=0,74, \lambda=0,75$ dan $\lambda=1$. Oleh karena itu akan ditentukan diagram kontrol mana yang paling sensitif. Kriteria untuk memilihnya adalah dengan memperhatikan rata-rata jarak nilai MEWMA tiap pengamatan pada masing-masing diagram kontrol dengan nilai pem- 


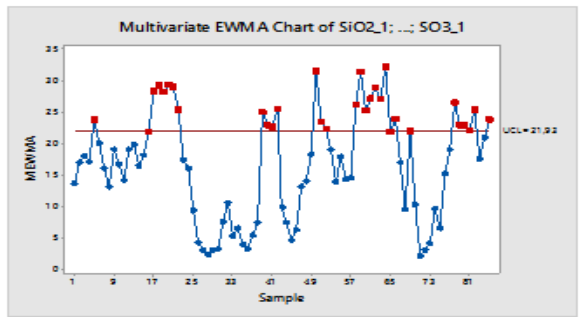

Gambar 3 Diagram Kontrol MEWMA $\lambda=0,25$

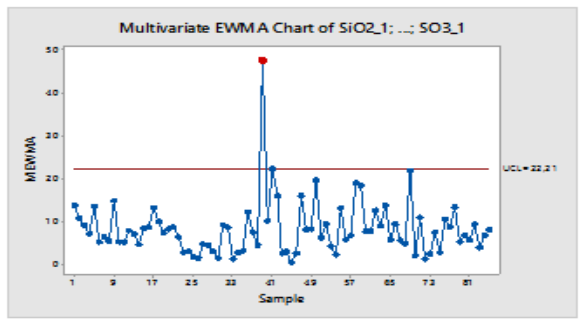

Gambar 5 Diagram Kontrol MEWMA $\lambda=0,75$

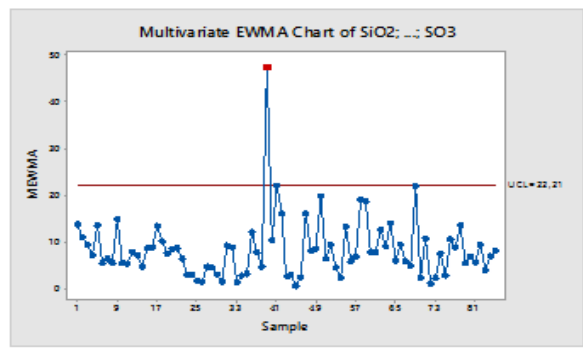

Gambar 7 Diagram Kontrol MEWMA $\lambda=0,74$

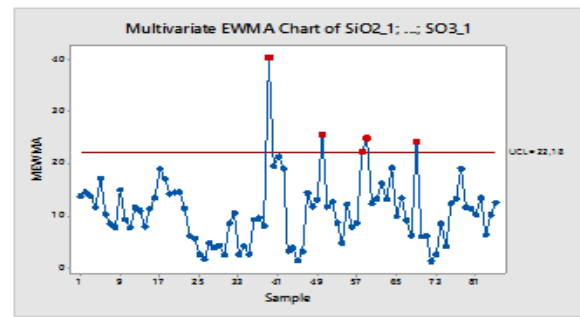

Gambar 4 Diagram Kontrol MEWMA $\lambda=0,5$

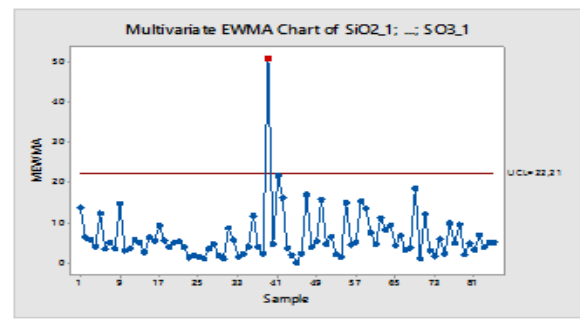

Gambar 6 Diagram Kontrol MEWMA $\lambda=1$

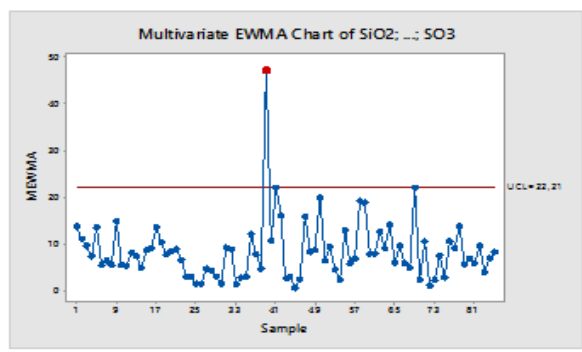

Gambar 8 Diagram Kontrol MEWMA $\lambda=0,73$

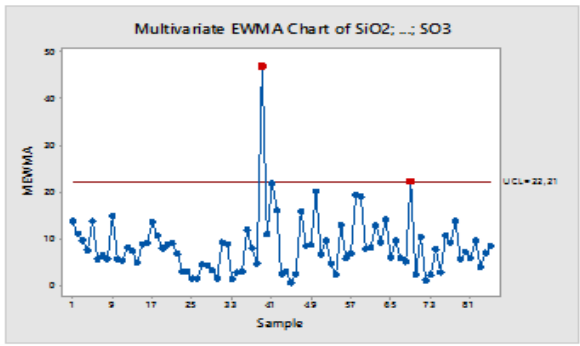

Gambar 9 Diagram Kontrol MEWMA $\lambda=0,72$

bobot berbeda terhadap batas kontrol atas masing-masing diagram kontrol. Tabel yang menjelaskan hal tersebut adalah sebagai berikut.

Tabel 1 merupakan rata-rata jarak nilai MEWMA tiap pengamatan terhadap batas kontrol atas dengan empat nilai pembobot. Rata-rata jarak nilai MEWMA tiap pengamatan terhadap batas kontrol atas dengan nilai rata-rata paling kecil 
Tabel 1. Rata-Rata Jarak Nilai MEWMA Terhadap Batas Kontrol Atas

\begin{tabular}{|c|c|}
\hline Pembobot & $\begin{array}{c}\text { Rata-Rata Jarak Nilai MEWMA } \\
\text { tiap Pengamatan terhadap Batas Kontrol Atas }\end{array}$ \\
\hline 0,73 & 14,35982 \\
\hline 0,74 & 14,44896 \\
\hline 0,75 & 14,53612 \\
\hline 1 & 16,22365 \\
\hline
\end{tabular}

terdapat pada diagram kontrol dengan nilai pembobot $\lambda=0,73$ yaitu sebesar 14,35982. Hal ini berarti diagram kontrol dengan pembobot sebesar 0,73 merupakan diagram kontrol yang paling sensitif jika dibandingkan dengan diagram kontrol MEWMA dengan pembobot yang lain. Tetapi tidak menutup kemungkinan, pembobot sebesar 0,74 dan 0,75 juga sudah menghasilkan diagram kontrol yang sensitif pada kasus ini. Sehingga diagram kontrol MEWMA dengan besar pembobot minimum 0,73 adalah diagram kontrol MEWMA yang paling optimal.

Setelah diperoleh diagram kontrol MEWMA optimal dengan nilai pembobot minimum, akan diidentifikasi pola yang terbentuk pada diagram kontrol tersebut. Berdasarkan Gambar 8, diketahui bahwa pola yang terbentuk adalah pola campuran. Setelah dilakukan konfirmasi kepada pihak PT. Semen Padang diketahui bahwa penyebab terjadinya pola campuran itu karena pemasok komponen bahan baku semen yang berbeda-beda. Komponen yang berasal dari pemasok berbeda adalah $\mathrm{SiO}_{2} 2, \mathrm{Al}_{2} \mathrm{O}_{3}$ dan $\mathrm{SO}_{3}$.

Dari Gambar 8, diketahui terdapat pengamatan out of control pada hari ke-39. Pengamatan out of control yang terjadi pada hari ke-39 ini, dicurigai berhubungan dengan adanya data sekunder $\mathrm{CaO}$ yang berada di bawah batas spesifikasi. Rendahnya kadar $\mathrm{CaO}$ yang terdapat pada bahan baku semen jenis PCC di PT. Semen Padang menyebabkan kualitas semen tidak terkendali. Setelah dilakukan konfirmasi kepada pihak PT. Semen Padang, diketahui bahwa terdapat jam-jam tertentu yang kurang optimal sehingga mempengaruhi kualitas bahan baku semen yang dihasilkan. Namun, setelah pengamatan out of control tersebut terdeteksi, akan langsung dilakukan perbaikan kualitas pada pengamatan selanjutnya sehingga tetap bahan baku semen yang dihasilkan tetap berkualitas sama.

\subsection{Analisis Kemampuan Proses}

Analisis kemampuan proses dapat menentukan seberapa besar keragaman proses terhadap spesifikasi. Untuk mengukur kemampuan proses dalam suatu simpangan, digunakan $C_{p}$ untuk melihat keterkaitan rentang antara spesifikasi atas, spesifikasi bawah dan simpangan baku proses secara khusus. Berikut hasil analisis kemampuan proses dalam suatu simpangan untuk masing-masing variabel.

Proses dikatakan memiliki keadaan baik jika memiliki nilai $C_{p}>1$. Dari hasil di atas dapat dilihat bahwa $C_{p}$ yang dihasilkan oleh masing-masing variabel lebih dari satu, maka dapat disimpulkan bahwa bahan baku produksi yang dimiliki oleh PT. Semen Padang sudah sangat baik. 
Tabel 2. Nilai $C_{p}$ untuk masing-masing variabel

\begin{tabular}{|c|c|c|}
\hline Variabel & $C_{p}$ & $C_{p k}$ \\
\hline $\mathrm{SiO} 2$ & 1,646329 & 1,537113 \\
\hline $\mathrm{Al} 2 \mathrm{O} 3$ & 5,183421 & 5,120108 \\
\hline $\mathrm{CaO}$ & 1,360596 & 0,173327 \\
\hline $\mathrm{SO} 3$ & 2,832556 & 2,228977 \\
\hline
\end{tabular}

Proses dikatakan memiliki akurasi yang bagus jika memiliki nilai $C_{p}=C_{p k}$. Jika $C_{p k} \geq 1$ maka proses sudah menghasilkan produk spesifikasi yang telah ditentukan. Jika $C_{p k}<1$ maka proses belum memiliki akurasi yang bagus. Penyebab $\mathrm{CaO}$ belum memiliki akurasi yang baik erat kaitannya dengan data bahan baku produksi $\mathrm{CaO}$ yang meannya mendekati batas spesifikasi bawah dan juga terdapat data yang berada di bawah batas spesifikasi bawah. Dari data sekunder yang diperoleh dan konfirmasi yang dilakukan kepada pihak PT. Semen Padang, diketahui bahwa data sekunder yang digunakan pada penelitian ini adalah data sekunder yang mengandung bahan baku semen dengan kualitas kurang baik dan masih butuh proses peningkatan kualitas ditahap selanjutnya.

Untuk menutupi kualitas yang kurang baik pada satu pengamatan tertentu, PT. Semen Padang berusaha meningkatkan kualitas pada waktu berikutnya. Bahan baku semen yang dihasilkan per hari akan dikumpulkan di dalam silo dan diaduk dengan tekanan udara tertentu. Sehingga bahan baku yang tidak terkendali pada hari tertentu akan diperbaiki kualitasnya dengan mencampur dengan bahan baku semen hari lainnya. Hal ini menyebabkan bahan baku semen yang dihasilkan tetap terjaga kualitasnya saat semen yang terdapat di dalam silo akan di proses ke tahap selanjutnya.

\section{Kesimpulan}

Dari pembahasan telah diperoleh hasil pengontrolan bahan baku produksi semen jenis PCC di PT. Semen Padang dengan menggunakan diagram kontrol MEWMA sebagai berikut.

(1) Diagram kontrol MEWMA dengan data bahan baku produksi semen jenis PCC di PT. Semen Padang pada 1 Januari 2015 hingga 31 Maret 2015 dengan besar pembobot sebesar $0,73,0,74,0,75$ dan 1 sudah optimal.

(2) Pembobot minimum yang menghasilkan diagram kontrol MEWMA optimal yang paling sensitif dengan satu pengamatan out of control pada data produksi semen jenis PCC di PT. Semen Padang dengan terdapat pada pembobot sebesar 0,73 .

(3) Analisis kemampuan proses memperlihatkan hasil bahwa bahan baku produksi semen jenis PCC di PT. Semen Padang sudah baik namun keakuratan proses pengontrolan $\mathrm{CaO}$ belum baik. Setelah dikonfirmasi, diketahui bahwa data sekunder yang digunakan pada penelitian ini adalah data sekunder yang mengandung bahan baku semen dengan kualitas yang kurang baik dan masih butuh proses peningkatan kualitas ditahap selanjutnya. 
14 Surya Puspita Sari dkk.

\section{Daftar Pustaka}

[1] Badan Standarisasi Nasional. 2014. Semen Portland. Jakarta

[2] Grant, E. L dan Richard, SL. 1996. Pengendalian Kualitas Statistik. Edisi Keenam Jilid 1. Jakarta, Erlangga

[3] Montgomery, DC. 2005. Statistical Quality Control: A Modern Introduction, Fifth Edition. John Wiley and Sons, New York

[4] Montgomery, DC. 2009. Introduction Statistical Quality Control. Sixth Edition. Jhon Wiley and Sons, Inc, New York

[5] Walpole, Ronal E. 1993. Pengantar Statistika. Edisi Ke-3. PT. Gramedia Pustaka Utama, Jakarta 